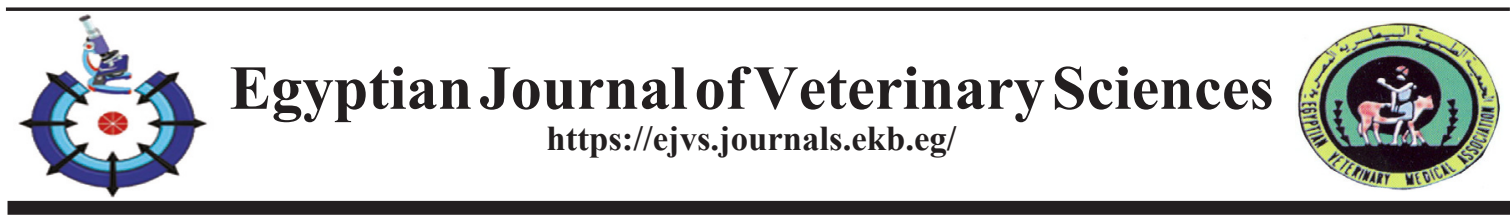

\title{
Comparative Study of Anti-staphylococcus aureus Effect of Chlorhexidine and Calcium Hydroxide in Dentine
}

Sanaa Saoud Ahmed*, Agharid Ali Alrasheed and Hiba Younis Khalaf Department of Microbiology, Veterinary Medicine Faculty, Tikrit University, Tikrit, Iraq

$\mathbf{T}$ HIS study was conducted to investigate the effect of different concentrations of chlorhexidine and calcium hydroxide on staphylococcus aureus bacteria isolated from the roots of the teeth of patients. As the bacteria were isolated from one of the patients arriving at the Teaching Hospital of the Faculty of Dentistry / University of Tikrit by taking a swab from the ends of the tooth root, and it was implanted and grown in media prepared for this purpose in the microbiology laboratory of the College of Veterinary Medicine / University of Tikrit. Graduated concentrations were used respectively from the chemical solutions of chlorhexidine and calcium hydroxide $(0.5 \%, 1 \%, 2 \%, 4 \%)$. Minimum Inhibitory (MIC) and Minimum Bactericidal Concentration (MBC) were calculated for the samples and it was found through the study that the concentration $2 \%$ of chlorhexidine compound after 36 hours caused inhibition of bacterial growth, as the tubes appeared transparent. The calcium hydroxide compound was found to cause inhibition of bacterial growth, 48 hours after the start of the treatment at a concentration of $4 \%$. We conclude from these results and the variation that occurred in the times of inhibition and the concentration of the inhibitory substance that chlorhexidine is more effective than calcium hydroxide in its use as a mouthwash and treatment of bacteria present in the roots of the teeth.

Keywords: chlorhexidine, calcium hydroxide, staphylococcus bacteria, dentine

\section{Introduction}

The elimination of germs present in the dental canals is one of the doctor's first concerns, because of their importance and a major role through the effect of these germs on the drug response and the effectiveness of treatment. Among those germs are the anaerobic bacteria that cause gum disease [1]. Among those germs are Staph. aureus bacteria that reside in the roots of the teeth and have been isolated from the root canals of the teeth and it has been shown that they are a major cause of disturbance of the healing process in the gum area [2].

Although the chemical - mechanical interference may contribute to reducing the number of bacteria present in the dental canals, the best way to sterilize the dental canals is to inject medicinal materials inside those channels to treat the bacterial causes in the event of infection [3]. The need for medical attention has become an urgent necessity at the present time, especially for those who are sensitive to some medicines, as the use of these medicines does not work because of the occurrence of pain and the presence of septic exudate [4]. For the previous reason, various types of intracanal medicament have been used, such as calcium hydroxide toothpaste and chlorhexidine gel.

Calcium hydroxide plays a major role in dental fillings Endodontics through its ability to form a solid tissue layer that acts as an anti-bacterial in addition to it acts as a physical barrier and prevents bacterial infection again and prevents the supply of bacteria in the teeth with the nutrients necessary

Corresponding author: Sanaa Saoud Ahmed, E-mail: sanaa.s.ahmed@tu.edu.iq, Tel: +9647715430060

(Received 02/06/2021; accepted 14/09/2021)

DOI. 10.21608/ejvs.2021.78839.1236

C2021 National Information and Documentation Centre (NIDOC) 
for their survival. Calcium hydroxide contains a hydroxyl ion that decomposes in the dentin ducts leads to an increase in the level of the acidic function $\mathrm{pH}$ which causes the decomposition of the cell wall of the endemic bacteria and then the death of those germs. The time required for that process is still unknown, and this process may be related to the presence of infectious exudation or not, the type of endemic bacteria, and the location of these germs in the root canals [5].

Chlorhexidine Gluconate is widely used in dental fillings due to its high efficacy in resisting bacteria as well as irrigation lotion and dental treatment Chlorhexidine inhibit the pathogenic Gram stain negative and positive bacteria present in the dental canals. The mechanism of action of chlorhexidine was explained by the containment of chlorhexidine on a positive charge as the positive charge in the chlorhexidine molecule interacts with the negative charge in the cell wall of the bacteria, which leads to damage to the cell wall. And the crossing of the chlorhexidine molecule into the bacteria causes the death of that bacterium [6]. This study was conducted to compare between effect of chlorhexidine and calcium hydroxide on the growth of bacteria Staph.aureus in the teeth of human.

\section{Material and Methods}

Sample collection and bacterial isolation

Samples were collected with sterile cotton swabs taken from the root area of the teeth from one of the patients arriving at the Teaching Hospital of the Faculty of Dentistry / University of Tikrit, and planted directly on the medium of mannitol salt agar, and then it was incubated at $37^{\circ} \mathrm{C}$ for 24 hours. The developing colonies were taken and stained with Gram stain, and the approved biochemical tests were performed [7].

Study of the inhibitory ability of chlorhexidine and calcium hydroxide preparations

1. Double dilutions of chlorhexidine and calcium hydroxide and two preparations of them were performed using the nutrient medium and using four dilutions for two studied compounds, respectively $(0.5 \%, 1 \%$, $2 \%$, and $4 \%$ ).

2. Add $1 \mathrm{ml}$ of bacterial suspension at a concentration of $\left(0.5 \times 8^{10}\right)$ to all tubes and incubated at $37^{\circ} \mathrm{C}$ for a period of $48 \mathrm{~h}$.

3. The minimum inhibitory concentration (MIC) was calculated for the highest dilution (lowest concentration) due to inhibition of bacterial growth as the tubes appeared transparent.

4. The Minimum Bactericidal Concentration (MBC) was calculated in the case of giving a negative result for bacterial culture in the tube when re-implanting from tubes to which medicinal preparations were added to the medium of brain heart infusion agar.

The results:

TABLE 1. Effect of chlorhexidine on the growth of bacteria Staph. aureus (MIC).

\begin{tabular}{ccccc}
\hline Dilution & $\mathbf{0 . 5} \%$ & $\mathbf{1} \%$ & $\mathbf{2} \%$ & $\mathbf{4} \%$ \\
\cline { 2 - 4 } Bacterial Type & $\mathbf{1 0 ~ H . ~}$ & $\mathbf{2 4} \mathbf{H .}$ & $\mathbf{3 6 ~ H . ~}$ & $\mathbf{4 8 ~ H . ~}$ \\
\hline Staph. aureus & ++ & + & - & - \\
\hline
\end{tabular}

$(+)$ : Indicates the presence of bacterial growth at the secondary culture

(-): It indicates the absence of bacterial growth at the secondary culture

TABLE 2. Effect of calcium hydroxide on the growth of bacteria Staph. aureus (MIC).

\begin{tabular}{ccccc} 
Dilution & $0.5 \%$ & $1 \%$ & $2 \%$ & $4 \%$ \\
\cline { 2 - 4 } Bacterial Type & 10 H. & 24 H. & 36 H. & 48 H. \\
\hline Staph. aureus & ++ & ++ & + \\
\hline
\end{tabular}

$(+)$ :Indicates the presence of bacterial growth at the secondary culture

$(-)$ : It indicates the absence of bacterial growth at the secondary culture 
TABLE 3. Effect of chlorhexidine on bacteria Staph.aureus (MBC).

\begin{tabular}{ccccc}
\hline \multirow{2}{*}{ Dilution } & $0.5 \%$ & $1 \%$ & $2 \%$ & $4 \%$ \\
\cline { 2 - 4 } Bacterial Type & $10 \mathrm{H.}$ & $24 \mathrm{H.}$ & $36 \mathrm{H.}$ & $48 \mathrm{H.}$ \\
\cline { 2 - 4 } Staph. aureus & + & + & - & - \\
\hline
\end{tabular}

$(+)$ :Indicates the presence of bacterial growth at the secondary culture

(-): It indicates the absence of bacterial growth at the secondary culture

TABLE 4. Effect of calcium hydroxide on bacteria Staph.aureus (MBC).

\begin{tabular}{ccccc}
\hline \multirow{2}{*}{ Dilution } & $0.5 \%$ & $1 \%$ & $2 \%$ & $4 \%$ \\
\cline { 2 - 5 } Bacterial Type & $10 \mathrm{H.}$ & $24 \mathrm{H.}$ & $36 \mathrm{H}$. & $48 \mathrm{H}$. \\
\hline Staph. aureus & + & + & + & - \\
\hline
\end{tabular}

$(+)$ :Indicates the presence of bacterial growth at the secondary culture

(-): It indicates the absence of bacterial growth at the secondary culture

\section{Discussion}

In the current study, it was found that the two compounds chlorhexidine and calcium hydroxide caused inhibition of the growth of Staph. aureus bacteria, which were isolated from the roots of the teeth, but the concentrations of the chemical compounds used in the experiment were not equal. Most of the previous studies indicated that these bacteria are killed by most chemicals, even if these substances have a low concentration. The results we obtained agreed with the Kontakiotis [8] who used chlorhexidine in his experimental study and observed killing Staph. aureus bacteria when using this compound and explained that the results obtained are that the chlorhexidine compound penetrates the cell wall by the adsorption process, and after penetrating into the cell, it destroys the internal components of the bacterial cell, causing it to exit outside the bacterial cell. If its concentration increases, it acts in the event of increased focus on destroying the cytoplasm of the target cell and stopping the process of producing proteins.

Furthermore, Ferraz [6] showed that the compound chlorhexidine is less toxic when used in the treatment of tooth decay as it does not cause a negative effect on the peripheral tissues of the teeth. In this study we noted that the calcium hydroxide compound caused inhibition and killed bacterial growth during the study period, the results obtained were in agreement with the findings of the Haapasalo [9]. In his study in which calcium hydroxide was used as an antibacterial against Staph. aureus bacteria and he was found that calcium hydroxide is not observed. The bacteria are in low concentrations and in a short time, but it can be fatal if used for a long time according to what the researcher explained, it has been explained that calcium hydroxide has the ability to absorb CO2 from the roots of the teeth, which affects the growth of bacteria because they depend on it in a way for their growth. Haenni [10] has observed in his experimental study that calcium hydroxide leads to killing germs, and he explained his results that the calcium hydroxide compound interacts with the dioxide present in the teeth, which leads to an increase in the $\mathrm{pH}$ level in the direction of the base, causing the death of the existing germs. Estrela [11] explained the death of germs during exposure to the calcium hydroxide compound, since the compound decomposes into calcium and the hydroxyl ion, and the hydroxyl ion affects all living tissues, including bacteria, as it causes various chemical reactions that cause cell wall damage, loss of electrons in the cell wall and loss in the enzymes needed to defend the living tissue and thus it affects the growth of bacteria and stops the growth and division of the cells of those germs.

Egypt. J. Vet. Sci. (special issue) (2021) 
The researcher Estrela [11] also indicated that the reason for inhibiting bacterial growth when using the calcium hydroxide compound is due to the fact that this compound causes stimulation of some enzymes such as alkaline phosphatase. These enzymes cause antibacterial effects by changing the $\mathrm{pH}$ in them and inhibiting the growth process and modulating in membrane biocompatibility due to its effect on proteins and fats phosphorylated in it. We conclude from this study the variation that occurred in the times of inhibition and the concentration of the inhibitory substance that chlorhexidine is more effective than calcium hydroxide in its use as a mouthwash and treatment of bacteria present in the roots of the teeth.

\section{Acknowledgment}

To all staff in the microbiology department in college of Vet. Medicine, Tikrit University.

\section{Funding statement}

Self-funding.

\section{Conflict of interest}

Authors declare no conflict of interest.

\section{Ethical consideration}

The study was conducted according to the ethical standards and institutional guides that recorded in Instructions of the Ministry of Higher education and scientific research.

\section{References}

1. Gomes, B. Variations in the susceptibilities of components of the endodontic microflora to biomechanical procedures. Journal of Dentistry, 29,47-55(2006).

2. Peciuliene, V. Isolation of Enterococcus faecalis in previously root-filled canals in a Lithuanian population. Journal of Endodontics, 25,593-595 (2009).

3. Byström, A. The antibacterial effect of camphorated paramonochlorophenol, camphorated phenol and calcium hydroxide in the treatment of infected root canals. Endodontics and Dental Traumatology, 1,170-175(2010).

4. Spangberg, L. Intracanal medicament. In: Ingle JI. Bakland LK. Endodontics.4th ed. Baltimore : Williams and Wilkins. 627-632(2011).
5. Siqueira, J. Intracanal medicaments: Evaluation of the antibacterial effects of chlorhexidine, metronidazole, and calcium hydroxide associated with three vehicles. Journal of Endodontics, 3, 167-169( 2012).

6. Ferraz, C. In vitro assessment of the antimicrobial action and the mechanical ability or chlorhexidine gel as an endodontic irrigant. Journal of Endodontics, 27,261-272(2017).

7. Quinn, P.J, Markey, B.K, Carter, M.E, Donnelly, W.J.C. and Leonard, F.C. Veterinary Microbiology and Microbial Disease. $1^{\text {st }}$ ed. Blackwell Science Ltd; London. pp. 163-167(2002).

8. Kontakiotis, E. In vitro study of the indirect action of calcium hydroxide on the anaerobic flora of the root canal. International Endodontic Journal, 28, 285-290(2018).

9. Haapasalo, H. Inactivation of local root canal medicaments by dentine: an in vitro study. International Endodontic Journal, 33, 126131(2016).

10. Haenni, S. Chemical and antimicrobial properties of calcium hydroxide mixed with irrigants solutions. Int. Endod. J., 36,100-105(2017).

11. Estrela, C. Molar conductivity of calcium hydroxide solutions. Braz. Endod. J., 5,1317(2018). 
العنقودية فقي علاجة لتأثير الكلوروهنانيكسيدين وهيدروكسيد الكالسيوم المضاد لبكتريا المكورات

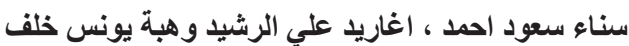

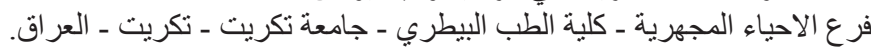

\begin{abstract}
اجريت هذه الدراسة لمعرفة تاثير تر اكيز مختلفة لكل من الكلورو هيكسيدين و هيدروكسيد الكالسيوم على بكتريا

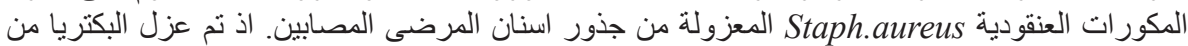

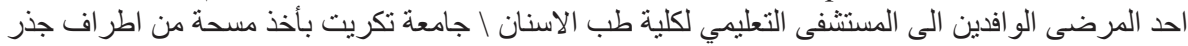

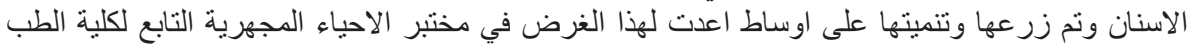

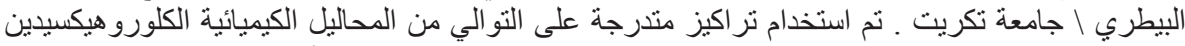

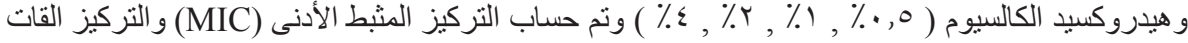

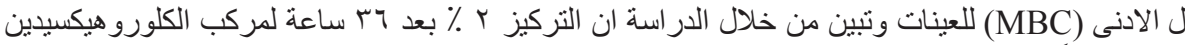

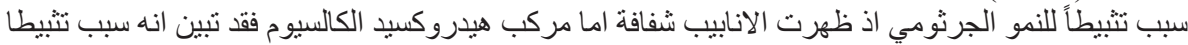

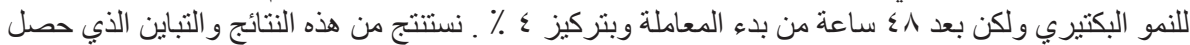

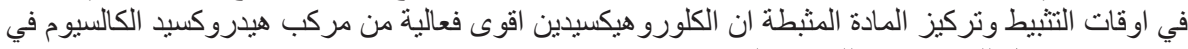

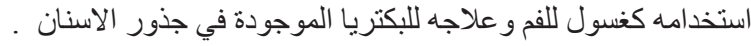

الكلمات المفتاحية : الكلورو هيكسيدين , هيدروكسيد الكالسيوم , بكتريا المكورات العنقودية , عاج الاسنان
\end{abstract}

